\title{
Chatter Suppression in Turning Operation Using Piezoelectric Device
}

学 ○前田 峰尚 (京大院) 正 松原 厚 (京大院) 山路 伊和夫 (京大院)

Minetaka MAEDA, Kyoto University, Kyoto daigaku-katsura, Nishikyo-ku, Kyoto

Atsushi MATSUBARA, Kyoto University, Iwao YAMAJI, Kyoto University

\section{1 緒 言}

切削加工において，びびり振動と呼ばれる工具・被削材 間の振動が加工面性状の悪化や工具の損傷に繋がるため古 くから問題となっている. 特に中ぐり加工では工具の剛性 が低いためびびり振動が発生しやすく，対策が求められて いる.びびり振動の主な原因は再生効果之呼ばれる現象で あり，その抑制にはコンプライアンス実部の負のピークを 低減することが重要となる(1).

一方，圧電素子を用いた振動制御が省スペース化に有利 な点から注目され, 研究が進められている。圧電素子を用 いた制振として, LR 回路を接続して圧電素子のキャパシ タンスと共振させることで振動を低減させる手法がある(2). また, 加速度信号増幅回路を用いて制振性能を高める手法 も提案されている ${ }^{(3)}$. これは能動的な制振手法と比べ安定 性の面で優れた手法である.

そこで本研究では, 中ぐりバイトに圧電素子を組み込み, LR 回路との電気的な共振を利用した制御を行うことでび びり振動を抑制する手法を提案する.コンプライアンス実 部のピークを低減する最適制御が可能であることをシミュ レーションおよび実験によって確かめ, さらに加工実験に よってびびり振動抑制の効果を検証する.

\section{2 コンプライアンス実部の制御}

実験に用いる工具の模式図を図 1 に示す.中ぐりバイトに 圧電素子を組み込み, LR 直列回路および加速度信号を用い ることにより電気的な吸振器として働かせることができる.

この工具を用いた加工においてびびり振動の発生に寄与 するのは, 主分力に対する切り込み方向の変位の伝達関数 $G_{\mathrm{xz}}$ であることが事前の実験により確認された. そこで回路 の值を調整し， $G_{x z}$ の実部の負のピークを低減する制御を行 った. 実験結果を図 2 に示す. 実部において負のピークが低 減されていることがわかる.提案手法を用いることでコンプ ライアンスの最適制御が可能であることが確かめられた。

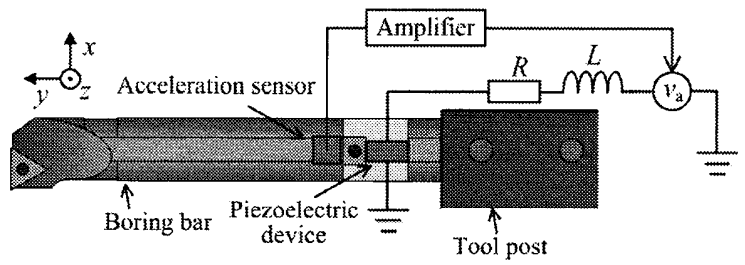

Fig. 1 Schematic view of a boring bar using a piezoelectric device, sensor voltage amplifier and a series LR circuit.
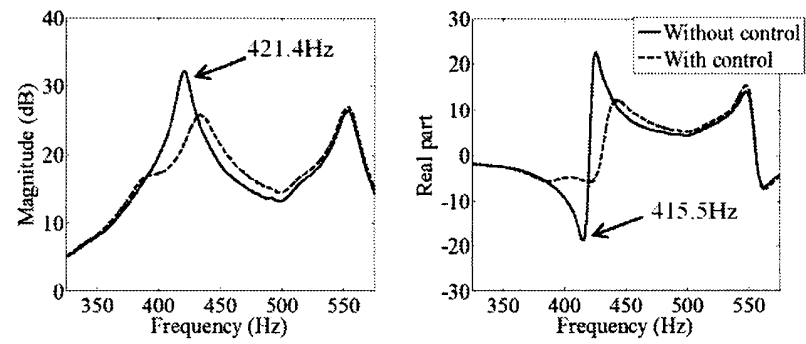

Fig. 2 Experimental results of compliance control.

\section{3 加 工 実 験}

実験は振動測定が行いやすいことから外面旋削加工を行 った．被削材にはS45C を用いた。制御を加えない場合と 制御を加えた場合について, 送り量を $0.2 \mathrm{~mm} / \mathrm{rev}$, 切り込 み量を $0.1 \mathrm{~mm}$, 主軸回転数を $270 \mathrm{rpm}$, 切削速度を $500 \mathrm{~mm} / \mathrm{sec}$ として同一切削条件での加工を行い，加工中の工具先端の 変位を測定した. 図 3,4 に測定された切り込み方向の変位 およびそのパワースペクトルを示す. 制御を加えない場合 には振幅 $10 \mu \mathrm{m}$ 以上の激しい振動が生じており, パワース ペクトルの $398.5 \mathrm{~Hz}$ 付近に鋭いピークが確認される.これ に対し制御を加えた場合には, 振動変位は $1 / 3$ 程度となり, パワースペクトルの $398.5 \mathrm{~Hz}$ 付近のピークが小さくなって いる. 以上の実験結果から, 提案手法の有効性が確認され た.
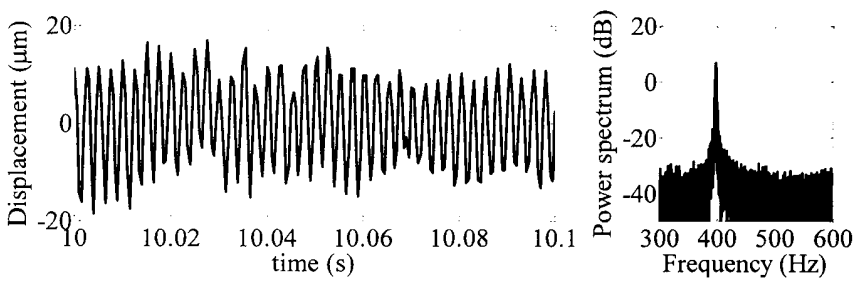

(a) Measured displacement

(b) Power spectrum Fig. 3 Experimental results without control.
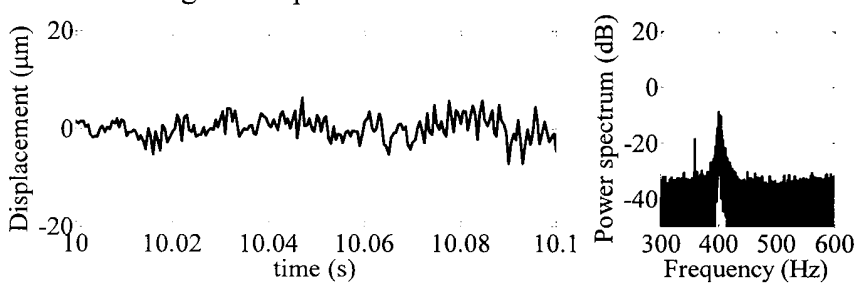

(a) Measured displacement

(b) Power spectrum Fig. 4 Experimental results with control.

\section{4 結 言}

中ぐり工具に圧電素子を組み込み, LR 回路と加速度信 号を用いた制振手法によってコンプライアンス実部のピー クを低減してびびり振動を抑制する手法を提案し, 実験に よって振動抑制効果が得られることを確認した。

\section{参考文献}

(1) Y. Altintas, and M. Weck, "Chatter Stability of Metal Cutting and Grinding", Annals of the CIRP, 53/2 (2004), pp. 619-642.

(2) N. W. Hagood, and A. VonFlotow, " Damping of Structural Vibrations with Piezoelectric Materials and Passive Electrical Networks ", Journal of Sound and Vibration, Vol. 146, No. 2 (1991), pp. 243-268.

（3）山田啓介，松久寛，宇津野秀夫，“圧電素子を用いた受 動制振のセンサ電圧増幅による性能向上”, Proceedings of Design and Dynamics Conference 2008, CD-ROM, No. 220 (2008), pp. 8-14. 